\title{
ASSESSMENT OF SUBSTRATE SOLUTION EXTRACTION METHODS FOR DETERMINATION OF CHEMICAL ATTRIBUTES IN SOILLESS CULTURE OF BELL PEPPER AND MELON ${ }^{1}$
}

\author{
ANDERSON FERNANDO WAMSER ${ }^{2 *}$, ARTHUR BERNARDES CECÍLIO FILHO ${ }^{3}$, CAMILA SENO \\ NASCIMENTO $^{3}$, CAROLINA SENO NASCIMENTO ${ }^{3}$, JUAN WALDIR MENDOZA CORTEZ ${ }^{4}$, RODRIGO HIYOSHI \\ DALMAZZO NOWAKI ${ }^{3}$
}

\begin{abstract}
The aim of this study was to evaluate the efficiency of the porous ceramic cup extractors, associated with ion meters, for the determination of nutrients availability for bell pepper and melon crops in substrate. Substrate solution was acquired using aqueous extract 1:1.5 (v/v) and also the porous ceramic cup extractor. Electrical conductivity (EC), $\mathrm{pH}$ and macronutrient contents were determined for the substrate solution through analytical method. The concentrations of $\mathrm{NO}_{3}{ }^{-}$and $\mathrm{K}^{+}$in the solutions obtained with porous ceramic cup extractors, and the $\mathrm{N}$ and $\mathrm{K}$ contents in the diagnostic leaf for nutritional evaluation were also determined. The concentrations of $\mathrm{NO}_{3}{ }^{-}$and $\mathrm{K}^{+}$using the porous ceramic cup extractors have strong correlation $(\mathrm{r}=0.96$ and 0.92 , respectively) with the ones obtained using the standard method, as well as a moderate correlation $(\mathrm{r}=0.65)$ and a strong one $(\mathrm{r}=0.71)$ with contents of $\mathrm{N}$ and $\mathrm{K}$, respectively, in the melon diagnostic leaf; and a weak correlation ( $\mathrm{r}=0.36$ and 0.26 , respectively) in the bell pepper diagnostic leaf. The use of porous ceramic cup extractors for obtaining the substrate solution and the determination of the $\mathrm{N}_{-} \mathrm{NO}_{3}{ }^{-}$and $\mathrm{K}^{+}$contents by means of specific ion meters are a fast method of evaluating nutrients availability in soilless cultures.
\end{abstract}

Keywords: Capsicum annuum L.. Cucumis melo L.. Aqueous extract. Plant nutrition.

\section{AVALIAÇ̃̃o DE MÉTODOS DE EXTRAÇ̃̃o DA SOLUÇ̃̃o DO SUBSTRATO PARA DETERMINAÇÃO DE ATRIBUTOS QUÍMICOS EM CULTIVO SEM SOLO DE PIMENTÃO E MELÃO}

RESUMO - O objetivo deste trabalho foi avaliar a eficiência de extratores de cápsula porosa, associados a medidores de íons específicos, para determinar a disponibilidade de nutrientes em pimentão e melão cultivados em substrato. A solução de substrato foi obtida utilizando o extrator aquoso 1:1,5 (v/v) e o extrator de cápsula porosa. A condutividade elétrica $(\mathrm{CE})$, o pH e a concentração dos macronutrientes na solução do substrato foram determinados por meio do método analítico. Além disso, foram determinadas as concentrações de $\mathrm{NO}_{3}$ e $\mathrm{K}^{+}$nas soluções obtidas com os extratores de cápsula porosa, bem como as concentrações de $\mathrm{N}$ e $\mathrm{K}$ na folha diagnose do estado nutricional. As concentrações de $\mathrm{NO}_{3}{ }^{-}$e $\mathrm{K}^{+}$obtidas por extratores de cápsula porosa apresentam forte correlação ( $\mathrm{r}=0,96$ e 0,92 , respectivamente) com as obtidas pelo método padrão, bem como correlação moderada $(\mathrm{r}=0,65)$ e forte $(\mathrm{r}=0,71)$ com as concentrações de $\mathrm{N}$ e $\mathrm{K}$, respectivamente, na folha diagnose do estado nutricional do melão e, correlação fraca ( $\mathrm{r}=0,36$ e 0,26 , respectivamente) na folha diagnose do estado nutricional do pimentão. A utilização de extratores de cápsula porosa para a obtenção da solução do substrato e, a determinação das concentrações de $\mathrm{N}_{-} \mathrm{NO}_{3}{ }^{-}$e $\mathrm{K}^{+}$por medidores de íons específicos, é um método rápido para avaliar a disponibilidade de nutrientes em cultivos sem solo.

Palavras-chave: Capsicum annuum L.. Cucumis melo L.. Extrator aquoso. Nutrição vegetal.

\footnotetext{
${ }^{*}$ Corresponding author

${ }^{1}$ Received for publication in 03/15/2021; accepted in 08/30/2021.

${ }^{2}$ Experimental Station of Caçador, Empresa de Pesquisa Agropecuária e Extensão Rural de Santa Catarina, Caçador, SC, Brazil; afwamser@epagri.sc.gov.br - ORCID: 0000-0002-3604-2179.

${ }^{3}$ Department of Plant Production, Universidade Estadual Paulista "Júlio de Mesquita Filho", Jaboticabal, SP, Brazil; arthur.cecilio@unesp.br - ORCID: 0000-0002-6706-5496, camilaseno@gmail.com - ORCID: 0000-0003-2558-5765, senocarolina@gmail.com - ORCID: 0000-0002-8096-5392, rodrigo.nowaki@gmail.com - ORCID: 0000-0002-0958-540X.

${ }^{4}$ Department of Plant Production, Universidad Nacional Agraria La Molina, La Molina, Peru; jmendoza@lamolina.edu.pe - ORCID: 00000002-2158-0943.
} 


\section{INTRODUCTION}

The constant monitoring of chemical attributes of the substrate solution in soilless culture enables the adjustment of fertigation management, hence avoiding the substrate salinity, besides keeping the proper balance of nutrients for the plants (GRATIERI et al., 2013; YONG-BEOM; EUNYOUNG; KI-YOUNG, 2013; WAMSER et al., 2017). The most endorsed methods for obtaining substrate solution for subsequent chemical characterization are the aqueous extracts at dilutions of $1: 1.5,1: 2.5$ and $1: 5(\mathrm{v} / \mathrm{v})$, the saturation extract and the Pour Thru method (FERMINO, 2014). The Pour Thru is the most common method for rapid chemical characterization of the substrate solution (GAVILÁN et al., 2015).

In soil cultivation, a widely evaluated and recommended method for regular collection of soil solution, also used for monitoring the fertility levels, is the use of porous ceramic cup extractors (OLIVEIRA et al., 2011; JIMÉNEZ; PLAZA; LAO, 2012; OLIVEIRA et al., 2013; SOUZA et al., 2013; OLIVEIRA et al., 2015; NOWAKI et al., 2017). More recently, this method has been used for cultivation systems in substrates in order to monitor the electrical conductivity (WRIGHT et al., 2009). Mota et al. (2011) and Marques et al. (2020) remark that the EC and the $\mathrm{pH}$ of the substrate solution extracted by porous ceramic cup extractor show strong correlation with the EC of the substrate solution obtained by Pour Thru method. On the other hand, Sambo et al. (2011) could only observe strong correlation between the porous ceramic cup extractor method and the Pour Thru method, but there were not significant correlations when compared with the lab tests from aqueous extract at dilution of $1: 2$ and from the saturation extracts for $\mathrm{EC}$ and $\mathrm{pH}$.

Regardless of the correlations between the porous ceramic cup extractor method and the other methods used for substrate solution obtainment, it should be pointed out that every determination method of available nutrients for plants also needs to show good correlation with the production variables or with the nutritional variables of the crop (ABREU et al., 2007a). In this regard, the studies conducted by Mota et al. (2011), Sambo et al. (2011) and Marques et al. (2020) do not correlate the chemical attributes determined in the substrate solution, obtained with the porous ceramic cup extractor, with the production variables or with the nutritional variables of the crop.

In parallel to the use of rapid methods for substrate solution collection performed by the grower, the determination of other chemical attributes is a recurring need, as well as the determination of $\mathrm{EC}$ and $\mathrm{pH}$, also in a rapid manner. In this regard, currently there are portable specific ion meters that enable the measurement of the concentrations of specific nutrients in the soil solution and in the substrate solutions, like $\mathrm{N}-\mathrm{NO}_{3}{ }^{-}$, $\mathrm{K}^{+}$and other important elements such as $\mathrm{Na}^{+}$ (MOTA et al., 2014).

In view of what has been exposed here, the objectives of the present study were: i) evaluate the efficiency of porous ceramic extractors in the determination of the nutrient availability for melon and bell pepper plants which were cultivated in coconut fiber and; ii) compare the use of specific ion meters $\mathrm{NO}_{3}^{-}$and $\mathrm{K}^{+}$with the lab methods of determination of $\mathrm{NO}_{3}^{-}$and $\mathrm{K}$ in the substrate solution.

\section{MATERIAL AND METHODS}

Experiment I - Relation of chemical attributes of substrate solution acquired using the porous ceramic cup extractor and aqueous extract 1:1.5 $(\mathbf{v} / \mathbf{v})$

The experiment was conducted, in the laboratory, in the period between June $4^{\text {th }}$ and $30^{\text {th }}$, 2011, using the commercial coconut fiber substrate Golden Mix ${ }^{\circledR}$ Misto type 98 (Amafibra, Pará, Brazil). The substrate solution had the following chemical attributes (aqueous extract 1:1.5 (v/v)): $\mathrm{pH}=5.4 ; \mathrm{EC}=1.0 \mathrm{dS} \mathrm{m}^{-1}$; and, in $\mathrm{mg} \mathrm{L}^{-1}, 3.3$ of $\mathrm{N}^{-\mathrm{NO}_{3}}{ }^{-}, 48.1$ of $\mathrm{P}, 40.2$ of $\mathrm{Cl}, 88.8$ of $\mathrm{S}, 5.2$ of $\mathrm{N}^{-\mathrm{NH}_{4}}{ }^{+}, 331.3$ of $\mathrm{K}, 12.3$ of $\mathrm{Na}, 8.0$ of $\mathrm{Ca}, 4.5$ of $\mathrm{Mg}, 1.0$ of $\mathrm{B}, 0.04$ of $\mathrm{Cu}, 0.3$ of $\mathrm{Fe}, 0.3$ of $\mathrm{Mn}$ and 0.3 of $\mathrm{Zn}$. The determinations were made from the filtrate of the aqueous extract, according to the methods described by Abreu et al. (2007b). The water retention capacity of the substrate at $10 \mathrm{cmH}_{2} \mathrm{O}$ (WRC10) was $427 \mathrm{~mL} \mathrm{~L}^{-1}$.

The treatments consisted of the application of five nutrient solutions with macronutrients corresponding to $0,100,200,300$ and $400 \%$ of the following macronutrient concentrations (FURLANI et al., 1999), in $\mathrm{mg} \mathrm{L}^{-1}: 174$ of $\mathrm{N}^{-N_{3}}, 24$ of $\mathrm{N}-\mathrm{NH}_{4}$, 39 of $\mathrm{P}, 183$ of K, 142 of Ca, 38 of $\mathrm{Mg}$, and 52 of S. The experimental design was completely randomized with four replicates.

The substrate was arranged in 8-L plastic bags with their bottom perforated, with the following dimensions: 22 centimeters high, 25 centimeters in upper diameter and 18 centimeters in lower diameter. The pots were submerged in individual buckets, which contained $12 \mathrm{~L}$ of nutrient solution, according to each treatment. They were kept there for 24 hours. After this period, the pots were taken out of the solution, kept hanging until full drainage and wrapped in a plastic film. After a 72-hour incubation period, a disturbed sample with $300 \mathrm{~cm}^{3}$ of substrate was collected from each pot, always from the layer between 12 and $18 \mathrm{~cm}$ depth, in order extract solution using the aqueous extract 1:1.5 (v/v) (FERMINO, 2014). Later, a porous ceramic cup extractor was put in each pot at a $15 \mathrm{~cm}$ depth, 
measured from half the length of the porous ceramic cup extractor. The porous ceramic cup extractors were made with PVC pipes that measured $1.27 \mathrm{~cm}$ in diameter and $50 \mathrm{~cm}$ in height. In one of the ends of the pipe, there was a ceramic cup with $6 \mathrm{~cm}$ height and in the other end there was a transparent polyethylene tube with a rubber stopper (BLANCO, 2006). With the aid of a manual vacuum pump, suction pressure of $600 \mathrm{~mm} \mathrm{Hg}$ was applied inside the tube. After 24 hours, the substrate solutions obtained by the porous ceramic cup extractor were collected and stored in $100 \mathrm{~mL}$ containers.

From the solutions present in the substrates obtained by the porous ceramic cup extractors and by the aqueous extracts 1:1.5 (v/v), EC, $\mathrm{pH}$ and macronutrient contents were determined by the analytical method (ABREU et al., 2007b). The levels of $\mathrm{NO}_{3}^{-}$and $\mathrm{K}^{+}$ions were also determined in the solutions obtained by the porous ceramic cup extractor by means of specific ion meters (Horiba, Twin Nitrate Meter model B-340 and Horiba, Twin Potassium Ion Meter model B-731, respectively).

The values of the variables obtained in the substrate solutions extracted by the porous ceramic cup extractor method were corrected for the substrate moisture in the aqueous extract 1:1.5 (v/v) method. The corrected values were determined by the following Equation 1:

$$
\mathrm{C}_{\text {aqueous extract 1:1.5 corrected }}=\frac{\mathrm{C}_{\text {porous ceramic cup extractor }} \mathrm{x} \text { Moisture } \text { porous ceramic cup extractor }_{\text {Moisture }}}{\text { aqueous extract 1:1.5 }}
$$

where $\mathrm{C}_{\mathrm{aqueous} \text { extract 1:1.5 corrected }}=\mathrm{EC}\left(\mathrm{dS} \mathrm{m} \mathrm{m}^{-1}\right)$, $\mathrm{pH}$ or nutrient concentration $\left(\mathrm{mg} \mathrm{L}^{-1}\right)$ obtained in the substrate solution extracted using the porous ceramic cup extractor method corrected to the moisture of substrate obtained using the aqueous extract 1:1.5

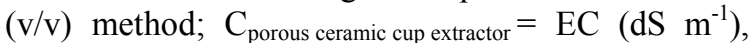
$\mathrm{pH}$ or nutrient concentration $\left(\mathrm{mg} \mathrm{L}^{-1}\right)$ obtained in the substrate solution extracted using the porous ceramic

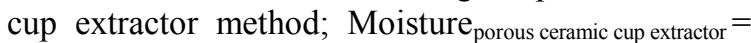
substrate moisture $\left(\mathrm{mL} \mathrm{L}^{-1}\right)$ at the beginning of the removal of solution from the substrate using the porous ceramic cup extractor; Moisture $_{\text {aqueous extractor } 1: 1.5=\text { substrate moisture }}$ $\left(\mathrm{mL} \mathrm{L}^{-1}\right)$ in the aqueous extract $1: 1.5(\mathrm{v} / \mathrm{v})$.

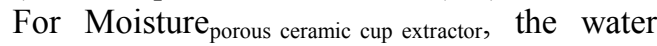
retention capacity of the substrate (WRC) of $427 \mathrm{~mL} \mathrm{~L}^{-1}$ was considered. Moisture ${ }_{\text {aqueous extract 1:1.5 }}$ was considered as the sum of Moisture $_{\text {porous ceramic cup extractor }}$ plus the moisture added with deionized water to maintain the proportion of 1 volume of substrate plus 1.5 volumes of water, that is, $427 \mathrm{~mL} \mathrm{~L}^{-1}+1.500 \mathrm{~mL} \mathrm{~L}^{-1}=1.927 \mathrm{~mL} \mathrm{~L}^{-1}$.

The chemical attributes of the two methods of substrate solution extraction were submitted to Pearson's linear correlation analysis (r) and linear regression.

Experiment II - Relationship between EC and N and $K$ concentrations in the substrate solution, extracted by porous ceramic cup extractors and aqueous extract 1:1.5 (v/v), with the levels of $\mathrm{N}$ and $K$ in the diagnostic leaf for nutritional status of the melon plant

The experiment was carried out in protected cultivation in Muzambinho, MG, Brazil, from July 1, 2011, to January 3, 2012. The average temperature and relative humidity in the period were $25^{\circ} \mathrm{C}$ and $67 \%$, respectively. The Bonus 2 melon hybrid was used. The treatments evaluated consisted of a combination of four $\mathrm{N}$ concentrations (112, 168, 224 and $280 \mathrm{mg} \mathrm{L}^{-1}$ ) and four $\mathrm{K}$ concentrations (156, 234, 312 and $390 \mathrm{mg} \mathrm{L}^{-1}$ ) in the nutrient solution. The experimental design was a randomized complete block, in a $4 \times 4$ factorial scheme, with three replicates. The plots consisted of $0.2 \mathrm{~m}$ wide, $0.19 \mathrm{~m}$ high and $3 \mathrm{~m}$ long cultivation channels, filled with Golden Mix ${ }^{\circledR}$ Mixed Type 80 commercial coconut fiber substrate (Amafibra, Pará, Brazil). The initial chemical attributes of the substrate obtained using the aqueous extract $1: 1.5(\mathrm{v} / \mathrm{v})$ method were: $\mathrm{pH}=$ $6.7 ; \mathrm{EC}=0.2 \mathrm{dS} \mathrm{m}^{-1}$; and in $\mathrm{mg} \mathrm{L}^{-1}, \mathrm{~N}^{-\mathrm{NO}_{3}}=0.3 ; \mathrm{N}$ $-\mathrm{NH}_{4}=1.2 ; \mathrm{K}=24.8 ; \mathrm{P}=2.27 ; \mathrm{Ca}=0.4 ; \mathrm{Mg}=0.1$; $\mathrm{S}=4.2 ; \mathrm{Na}=1.4 ; \mathrm{B}=0.1 ; \mathrm{Cu}=0.01 ; \mathrm{Fe}=0.3 ; \mathrm{Mn}$ $=0.01$ and $\mathrm{Zn}=0.03$. The seedlings were transplanted to the definitive channels at a spacing of $1.10 \mathrm{~m}$ between channels and $0.40 \mathrm{~m}$ between plants, totaling eight plants per plot. The cultural practices were performed as described by Gratieri et al. (2013).

The crop irrigation was localized by drip irrigation system, using one anti-draining and pressure-compensating dripper per plant, with a nominal flow of $4.0 \mathrm{~L} \mathrm{~h}^{-1}$. Fertigation began to be applied soon after seedling transplantation and continued until the end of the harvest. Fertigation was performed whenever the substrate tension was less than $-4.0 \mathrm{kPa}$. Fertigation control was carried out by means of the MRI-10/2 electronic irrigation controller connected to the Irrigas ${ }^{\circledR}$ sensors with a bubbling tension of $15 \mathrm{kPa}$.

The contents of $\mathrm{N}$ and $\mathrm{K}$ in the diagnostic leaf of the nutritional status of the plants were evaluated at 40 days after transplantation (DAT). Samples of the substrate solution were obtained at 20,40 and 60 DAT. In the porous ceramic cup extractor method, one extractor was used per plot at distance of $0.20 \mathrm{~m}$ from the melon stem. The characteristics of the extractor and the extraction methodology follow those of Experiment I. For the extraction of the 
substrate solution by the aqueous extract $1: 1.5(\mathrm{v} / \mathrm{v})$, a sample of $2 \mathrm{~L}$ of substrate was collected per plot, between plants, and the collection site was not repeated in the subsequent ones. In both methods of substrate solution extraction, $\mathrm{pH}, \mathrm{EC}, \mathrm{K}^{+}$ concentration (Horiba, Twin Potassium Ion Meter model B-731) and total $\mathrm{N}$ were evaluated. The contents of the ion $\mathrm{NO}_{3}{ }^{-}$were not evaluated by the specific ion meter in the present research. The chemical attributes of both methods and the characteristics of the evaluated plants were submitted to Pearson's linear correlation analysis (r).

Experiment III - Relation of EC and $\mathrm{N}$ and $\mathrm{K}$ concentrations in the substrate solution, extracted by porous ceramic cup extractors and aqueous extract 1:1.5 (v/v), with $\mathrm{N}$ and $\mathrm{K}$ contents in the diagnostic leaf of bell pepper nutritional status

The experiment was carried out in protected cultivation in Jaboticabal, SP, Brazil, from November 9, 2012, to July 19, 2013. The average temperature and relative humidity in the period were $23.3{ }^{\circ} \mathrm{C}$ and $79 \%$, respectively. The yellow bell pepper hybrid Eppo was used. The treatments consisted of the combination of four concentrations of $\mathrm{N}\left(84,126,168\right.$ and $\left.210 \mathrm{mg} \mathrm{L}^{-1}\right)$ and four concentrations of $\mathrm{K}\left(117,195,273\right.$ and $\left.351 \mathrm{mg} \mathrm{L}^{-1}\right)$ in the nutrient solution. The experimental design was randomized complete block, with three replicates. The plots consisted of cultivation channels with 0.2 $\mathrm{m}$ width, $0.25 \mathrm{~m}$ height and $4.8 \mathrm{~m}$ length, filled with Golden Mix ${ }^{\circledR}$ Mixed Type 98 commercial coconut fiber substrate (Amafibra, Pará, Brazil). The initial chemical attributes of the substrate obtained by aqueous extract $1: 1.5(\mathrm{v} / \mathrm{v})$ method were the same as those described in Experiment I. The seedlings were transplanted to the definitive channels at spacing of $1.25 \mathrm{~m}$ between channels and $0.40 \mathrm{~m}$ between plants, totaling 12 plants per plot. The plants were grown according to Wamser et al. (2017). The system, the management and the irrigations control were the same as those described in Experiment II.

The contents of $\mathrm{N}$ and $\mathrm{K}$ were evaluated in diagnostic leaf of nutritional status of plants at 40 , $61,88,111,132,155,181,213$ and 252 DAT. The substrate solution samples were obtained at 40, 61, $88,111,132,155,181,213$ and 252 DAT. The methodology of soil solution extraction by porous ceramic cup extractor and aqueous extract 1:1.5 (v/v) is the same as the one described in Experiment II. In the aqueous extract $1: 1.5(\mathrm{v} / \mathrm{v})$ method, the $\mathrm{pH}, \mathrm{EC}$ and $\mathrm{N}-\mathrm{NO}_{3}, \mathrm{~K}$ and total $\mathrm{N}$ contents were evaluated, according to the methods described by Abreu et al. (2007b). In porous ceramic cup extractor method, the
$\mathrm{pH}, \mathrm{EC}$ and the $\mathrm{N}^{-} \mathrm{NO}_{3}{ }^{-}$and $\mathrm{K}^{+}$ion contents were evaluated by the specific ion meters described in Experiment I. The statistical analysis procedures were the same as those described in Experiment II.

\section{RESULTS AND DISCUSSION}

In Experiment I, the chemical attributes in the substrate solutions obtained by porous ceramic cup extractor correlated in a strong and positive way with those obtained by aqueous extract $1: 1.5(\mathrm{v} / \mathrm{v})$ $(\mathrm{r}>0.82)$ (Table 1). The concentrations of $\mathrm{N}-\mathrm{NO}_{3}$ and $\mathrm{K}$ in substrate solution obtained by the porous ceramic cup extractor had higher correlation with those obtained by aqueous extract $1: 1.5(\mathrm{v} / \mathrm{v})$ when these were determined by specific ion meters $(\mathrm{r}=0.96$ and 0.92$)$, in comparison with the analytical method $(\mathrm{r}=0.82$ and 0.89$)$.

The linear regressions between porous ceramic cup extractor method and aqueous extract $1: 1.5(\mathrm{v} / \mathrm{v})$ fitted significantly $(\mathrm{p}<0.01)$, explaining $78 \%$ to $96 \%$ of the variations obtained between the two methods of substrate solution extraction (Figures 1, 2 and 3). Except for $\mathrm{N}-\mathrm{NO}_{3}$, applying the analytical method, and for total $\mathrm{N}$ concentration, the coefficients of linear regression (b) for other chemical attributes were near 1.0, varying from 0.7988 to 1.2479 . The linear regression coefficient between the methods of substrate solution extraction for $\mathrm{N}-\mathrm{NO}_{3}$ concentration was lower when substrate solution obtained by the porous ceramic cup extractor was analyzed by analytical method $(b=0.5433)$, when compared to specific ion meter $(b=1.0854)$ (Figure 2B). The fit of linear regressions was also lower in analytical method $\left(\mathrm{R}^{2}=0.80\right)$ when compared to specific ion meter $\left(\mathrm{R}^{2}=0.92\right)$.

Differently from $\mathrm{N}-\mathrm{NO}_{3}$, the linear regression coefficients of both determination methods of $\mathrm{K}$ concentration in substrate solution extracted by porous ceramic cup were very close $(b=0.7988$, in specific ion meter, and $b=0.8065$, in analytical method) (Figure 2D), when compared with aqueous extract 1:1.5 (v/v) method. However, just like N$\mathrm{NO}_{3}$, the fit of linear regressions was lower in the analytical method $\left(\mathrm{R}^{2}=0.78\right)$ when compared to specific ion meter $\left(\mathrm{R}^{2}=0.84\right)$.

In Experiment II, the chemical attributes EC, $\mathrm{N}$ and $\mathrm{K}$ of substrate solution extracted by porous ceramic cup and aqueous extract $1: 1.5(\mathrm{v} / \mathrm{v})$ methods correlated in a strong and positive way $(\mathrm{r}=0.79,0.84$ and 0.82 respectively for EC, $\mathrm{N}$ and $\mathrm{K}$ ) (Table 2). The correlation between the two methods of substrate solution extraction for $\mathrm{pH}$ was significant and positive, but very weak $(\mathrm{r}=0.19)$. 
Table 1. Correlations of chemical attributes of substrate solution obtained by porous ceramic cup extractor (pc) with the chemical attributes of substrate solution obtained by aqueous extract (ae) 1:1.5 (v/v).

\begin{tabular}{|c|c|}
\hline Chemical attributes correlated & Pearson linear correlation \\
\hline $\mathrm{EC}(\mathrm{ae}) \times \mathrm{CE}(\mathrm{pc})$ & $0.97 *$ \\
\hline $\mathrm{pH}(\mathrm{ae}) \times \mathrm{pH}(\mathrm{pc})$ & $0.98^{*}$ \\
\hline $\mathrm{N}-\mathrm{NO}_{3}(\mathrm{ae}) \times \mathrm{N}-\mathrm{NO}_{3}(\mathrm{pc})$ (analytical method) & $0.82 *$ \\
\hline $\mathrm{N}-\mathrm{NO}_{3}(\mathrm{ae}) \times \mathrm{N}-\mathrm{NO}_{3}(\mathrm{pc})$ (specific ion meters) & $0.96^{*}$ \\
\hline $\mathrm{N}-\mathrm{NH}_{4}(\mathrm{ae}) \times \mathrm{N}-\mathrm{NH}_{4}(\mathrm{pc})$ & $0.94 *$ \\
\hline $\mathrm{N}(\mathrm{ae}) \times \mathrm{N}(\mathrm{pc})$ & $0.90 *$ \\
\hline $\mathrm{P}(\mathrm{ae}) \times \mathrm{P}(\mathrm{pc})$ & $0.93 *$ \\
\hline $\mathrm{K}(\mathrm{ae}) \times \mathrm{K}(\mathrm{pc})$ (analytical method) & $0.89 *$ \\
\hline $\mathrm{K}(\mathrm{ae}) \times \mathrm{K}(\mathrm{pc})$ (specific ion meters) & $0.92 *$ \\
\hline $\mathrm{Ca}(\mathrm{ae}) \times \mathrm{Ca}(\mathrm{pc})$ & $0.98^{*}$ \\
\hline $\operatorname{Mg}(\mathrm{ae}) \times \operatorname{Mg}(\mathrm{pc})$ & $0.95^{*}$ \\
\hline $\mathrm{S}(\mathrm{ae}) \times \mathrm{S}(\mathrm{pc})$ & $0.91 *$ \\
\hline
\end{tabular}

*Significative Pearson linear correlation at 0.05 level of significance.
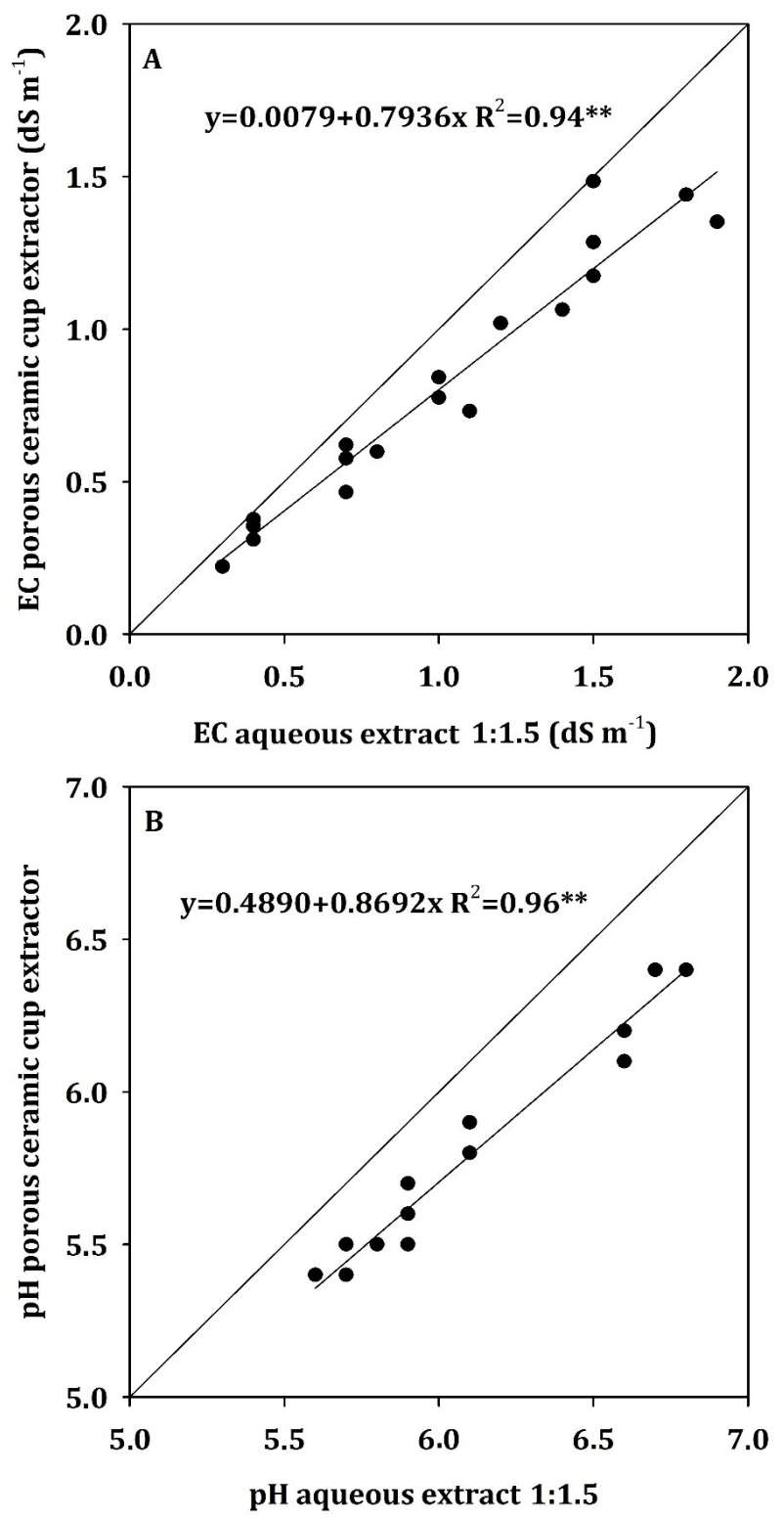

Figure 1. Relation between the aqueous extraction method 1:1.5 (v/v) and porous ceramic cup extractor method for electric conductivity (A) and the $\mathrm{pH}(\mathrm{B})$ of coconut fiber substrate solution analyzed by analytical method. 

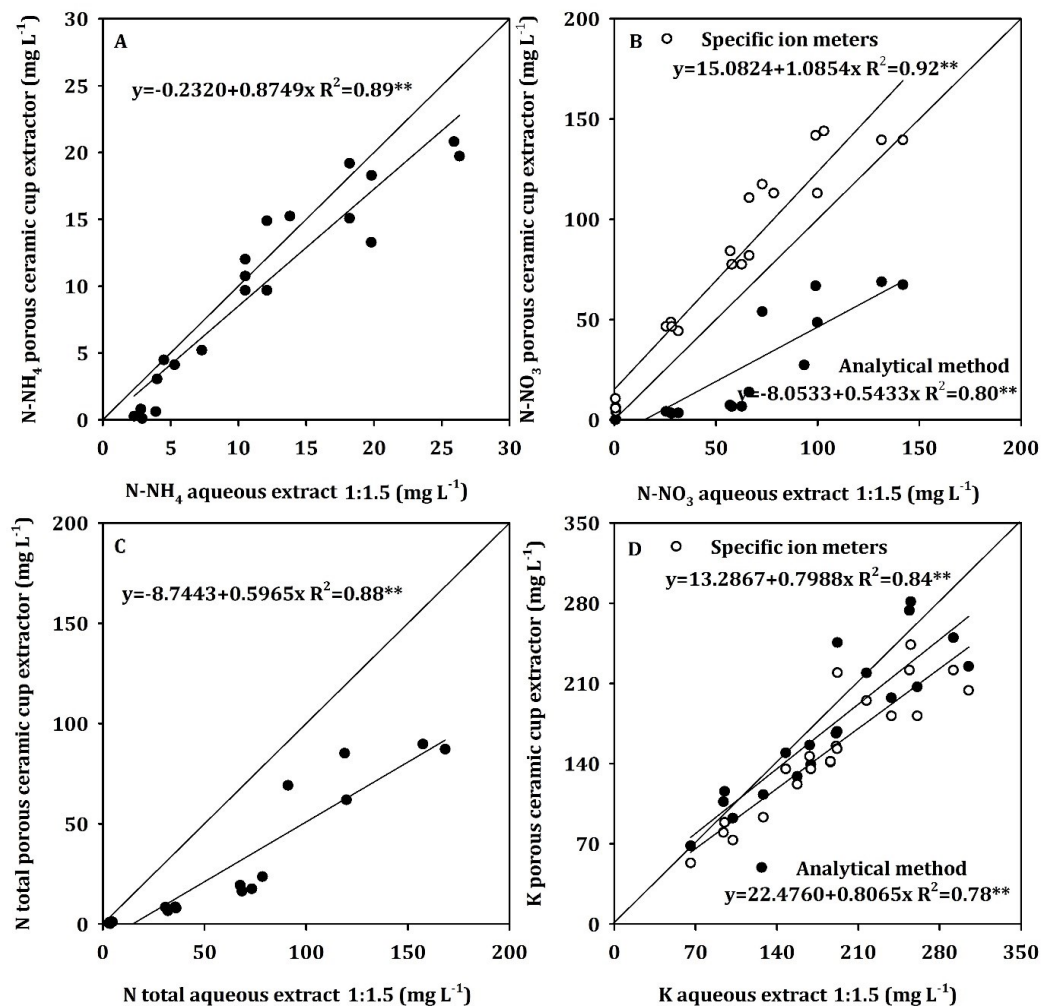

Figure 2. Relation between the aqueous extraction method 1:1.5 (v/v) and the porous ceramic cup extractor method for the contents of $\mathrm{N}-\mathrm{NH}_{4}(\mathrm{~A}), \mathrm{N}_{-} \mathrm{NO}_{3}(\mathrm{~B})$, total $\mathrm{N}(\mathrm{C})$ e $\mathrm{K}(\mathrm{D})$, of coconut fiber substrate solution, analytically determined and by specific ion meters.
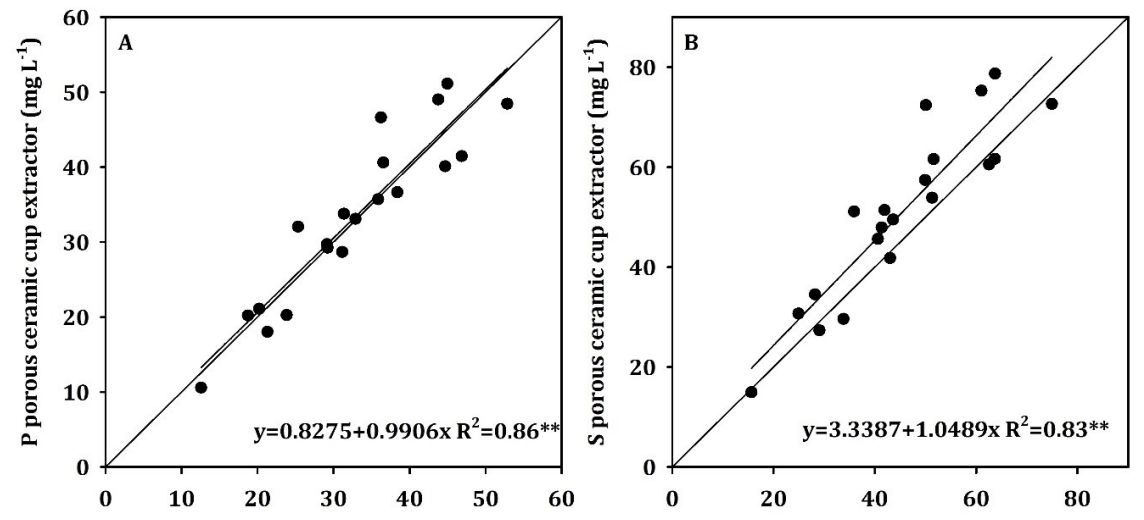

P aqueous extract 1:1.5 (mg $\left.\mathrm{L}^{-1}\right)$
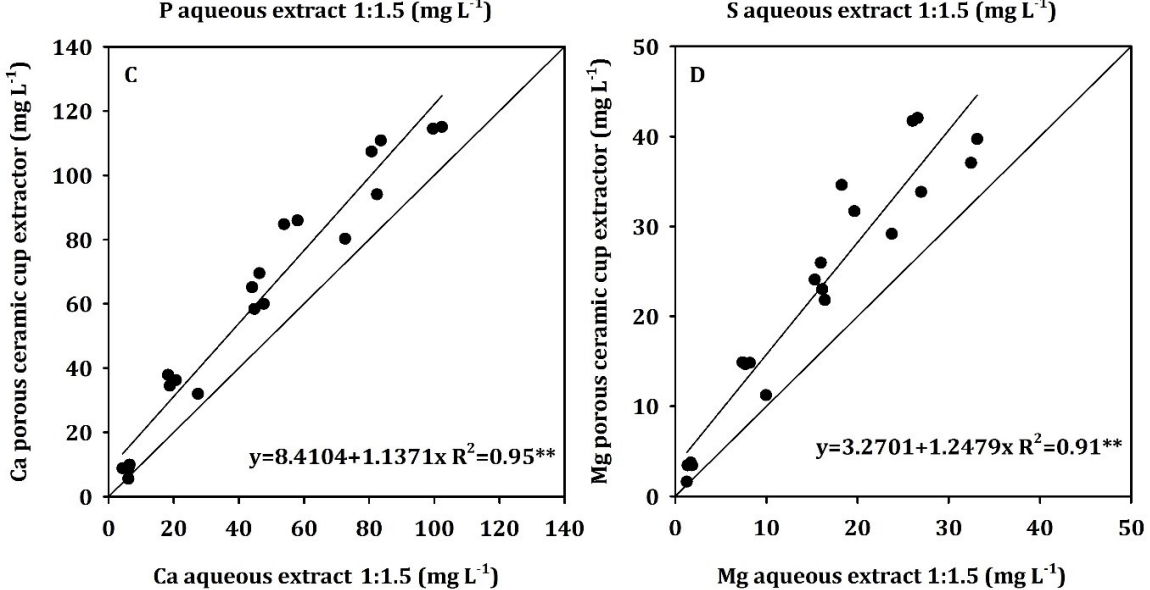

Figure 3. Relation between the aqueous extraction method 1:1.5 (v/v) and the porous ceramic cup extractor method for the contents of $\mathrm{P}(\mathrm{A}), \mathrm{S}(\mathrm{B}), \mathrm{Ca}(\mathrm{C})$ and $\mathrm{Mg}(\mathrm{D})$, of coconut fiber substrate solution. 
Table 2. Pearson's linear correlation between the chemical attributes of substrate solution obtained by aqueous extract (ae) $1: 1.5(\mathrm{v} / \mathrm{v})$ and by porous ceramic cup extractors (pc) at 20, 40 and 60 days after transplantation (DAT) for melon cropand between the chemical attributes of substrate solution and the leaf contents of nitrogen $(\mathrm{N})$ and potassium $(\mathrm{K})$ in diagnostic leaf of melon nutritional status at 40 DAT.

\begin{tabular}{|c|c|c|c|c|c|c|c|c|}
\hline & \multicolumn{8}{|c|}{ Melon experiment, Muzambinho (MG, Brazil) } \\
\hline & $\mathrm{pH}(\mathrm{ae})$ & $\mathrm{CE}(\mathrm{ae})$ & $\mathrm{N}(\mathrm{ae})$ & $\mathrm{K}(\mathrm{ae})$ & $\mathrm{pH}(\mathrm{pc})$ & $\mathrm{CE}(\mathrm{pc})$ & $\mathrm{N}(\mathrm{pc})$ & $\mathrm{K}(\mathrm{pc})$ \\
\hline & \multicolumn{8}{|c|}{ Evaluation at 20,40 e 60 DAT } \\
\hline $\mathrm{pH}(\mathrm{ae})$ & & $-0.71 *$ & $-0.72 *$ & $-0.34^{*}$ & $0.19 *$ & $-0.62 *$ & $-0.51 *$ & $-0.43 *$ \\
\hline $\mathrm{CE}(\mathrm{ae})$ & & & $0.68 *$ & $0.84 *$ & $-0.19 *$ & $0.79 *$ & $0.42 *$ & $0.75 *$ \\
\hline $\mathrm{N}(\mathrm{ae})$ & & & & $0.49 *$ & $-0.29 *$ & $0.65^{*}$ & $0.84 *$ & $0.59^{*}$ \\
\hline $\mathrm{K}(\mathrm{ae})$ & & & & & -0.14 & $0.72 *$ & $0.30 *$ & $0.82 *$ \\
\hline $\mathrm{pH}(\mathrm{pc})$ & & & & & & -0.15 & $-0.40 *$ & -0.15 \\
\hline $\mathrm{CE}(\mathrm{pc})$ & & & & & & & $0.58 *$ & $0.88 *$ \\
\hline $\mathrm{N}(\mathrm{pc})$ & & & & & & & & $0.50 *$ \\
\hline \multicolumn{9}{|l|}{$\mathrm{K}(\mathrm{pc})$} \\
\hline PFC & -0.12 & 0.09 & $0.43 *$ & 0.10 & $-0.20 *$ & $0.18^{*}$ & $0.59 *$ & $0.19 *$ \\
\hline & \multicolumn{8}{|c|}{ Evaluation at $40 \mathrm{DAT}$} \\
\hline $\mathrm{N}$ (folha) & $0.31 *$ & $-0.47 *$ & $0.40 *$ & $-0.31 *$ & -0.04 & 0.15 & $0.65 *$ & 0.08 \\
\hline K(folha) & 0.00 & $0.61 *$ & 0.07 & $0.71 *$ & 0.23 & $0.53 *$ & -0.16 & $0.71 *$ \\
\hline
\end{tabular}

$(\mathrm{ae})=$ substrate solution obtained by aqueous extract method 1:1.5 (v/v) and lab analysis of all chemical attributes, except $\mathrm{K}$ contents which were obtained by specific ion meters; $(\mathrm{pc})=$ substrate solution obtained by porous ceramic cup extractors method and lab analysis of all chemical attributes, except $\mathrm{K}$ contents which were obtained by specific ion meters; * Significative Pearson linear correlation at 0.05 level of significance.

The $\mathrm{N}$ contents in diagnostic leaf of melon nutritional status at 40 DAT correlated moderately with $\mathrm{N}$ contents in substrate solution obtained by both extractors (Table 2). However, the correlation was higher when the porous ceramic cup extractor was used $(\mathrm{r}=0.65)$, compared to the aqueous extract $1: 1.5(\mathrm{v} / \mathrm{v})(\mathrm{r}=0.40)$. The $\mathrm{K}$ contents in diagnostic leaf of melon nutritional status at 40 DAT strongly correlated with $\mathrm{K}^{+}$concentrations substrate solution for both extractors, in such a way that there was no distinction in correlation degree $(\mathrm{r}=0.71)$ (Table 2).

In Experiment III, the chemical attributes EC, $\mathrm{N}$ and $\mathrm{K}$ of substrate solution acquired by extractor methods of porous ceramic cup and aqueous extract $1: 1.5(\mathrm{v} / \mathrm{v})$ correlated in a strong and positive way $\left(\mathrm{r}=0.76,0.81\right.$ and 0.71 respectively for $\mathrm{EC}, \mathrm{NO}_{3}{ }^{-}$and K) (Table 3). This result is similar to that from the Experiment II (Table 2). The correlation between the two methods of substrate solution extraction for $\mathrm{pH}$ was significant and positive, but moderate $(\mathrm{r}=0.50)$.

Table 3. Pearson's linear correlation between the chemical attributes of substrate solution obtained by aqueous extract (ae) $1: 1.5(\mathrm{v} / \mathrm{v})$ and by porous ceramic cup extractors (pc) at 40,61, 88, 111, 132, 155, 181, 213 and 252 DAT for bell pepper, and between the chemical attributes of substrate solution and the leaf contents of nitrogen $(\mathrm{N})$ and potassium $(\mathrm{K})$ in diagnostic leaf of bell pepper nutritional status at 40,61, 88, 111, 132, 155, 188, 213 and 252 DAT.

\begin{tabular}{cccccccccc}
\hline & \multicolumn{9}{c}{ Bell pepper experiment. Jaboticabal (SP. Brazil) } \\
\hline & $\mathrm{pH}(\mathrm{ae})$ & $\mathrm{CE}(\mathrm{ae})$ & $\mathrm{NO}_{3}(\mathrm{ae})$ & $\mathrm{N}(\mathrm{ae})$ & $\mathrm{K}(\mathrm{ae})$ & $\mathrm{pH}(\mathrm{pc})$ & $\mathrm{CE}(\mathrm{pc})$ & $\mathrm{NO}_{3}(\mathrm{pc})$ & $\mathrm{K}(\mathrm{pc})$ \\
\hline $\mathrm{pH}(\mathrm{ae})$ & & $-0.21^{*}$ & $-0.22^{*}$ & $-0.23^{*}$ & $0.05^{*}$ & $0.50^{*}$ & 0.02 & $-0.13^{*}$ & $0.22^{*}$ \\
$\mathrm{CE}(\mathrm{ae})$ & & & $0.83^{*}$ & $0.84^{*}$ & $0.78^{*}$ & $-0.24^{*}$ & $0.76^{*}$ & $0.69^{*}$ & $0.54^{*}$ \\
$\mathrm{NO}_{3}(\mathrm{ae})$ & & & & $0.99^{*}$ & $0.53^{*}$ & $-0.36^{*}$ & $0.63^{*}$ & $0.81^{*}$ & $0.39^{*}$ \\
$\mathrm{~N}(\mathrm{ae})$ & & & & & $0.53^{*}$ & $-0.37^{*}$ & $0.63^{*}$ & $0.80^{*}$ & $0.38^{*}$ \\
$\mathrm{~K}(\mathrm{ae})$ & & & & & & 0.10 & $0.65^{*}$ & $0.51^{*}$ & $0.71^{*}$ \\
$\mathrm{pH}(\mathrm{pc})$ & & & & & & & -0.10 & $-0.29^{*}$ & $0.16^{*}$ \\
$\mathrm{CE}(\mathrm{pc})$ & & & & & & & & $0.71^{*}$ & $0.81^{*}$ \\
$\mathrm{NO}$ (pc) & & & & & & & & & $0.52^{*}$ \\
$\mathrm{~K}(\mathrm{pc})$ & & & & & & & & & \\
\hline $\mathrm{PFC}$ & $0.20^{*}$ & $0.27^{*}$ & $0.15^{*}$ & $0.16^{*}$ & $0.16^{*}$ & -0.02 & $0.31^{*}$ & $0.18^{*}$ & $0.16^{*}$ \\
$\mathrm{~N}(\mathrm{folha})$ & $-0.23^{*}$ & $0.48^{*}$ & $0.42^{*}$ & $0.43^{*}$ & $0.14^{*}$ & $-0.33^{*}$ & $0.41^{*}$ & $0.36^{*}$ & $0.11^{*}$ \\
$\mathrm{~K}($ folha) & -0.03 & $0.43^{*}$ & $0.36^{*}$ & $0.36^{*}$ & $0.26^{*}$ & -0.03 & $0.42^{*}$ & $0.34^{*}$ & $0.26^{*}$ \\
\hline
\end{tabular}

$(\mathrm{ae})=$ substrate solution obtained by aqueous extract method 1:1.5 (v/v) and lab analysis of all chemical attributes, except $\mathrm{K}$ contents which were obtained by specific ion meters; $(\mathrm{pc})=$ substrate solution obtained by porous ceramic cup extractors method and lab analysis of all chemical attributes, except $\mathrm{K}$ contents which were obtained by specific ion meters; * Significative Pearson linear correlation at 0.05 level of significance. 
The $\mathrm{N}$ contents in diagnostic leaf of bell pepper nutritional status correlated in a positive and moderate way with the $\mathrm{N}$ concentrations in substrate solution acquired by both extractors (Table 3). However, the correlation was higher when the aqueous extract $1: 1.5(\mathrm{v} / \mathrm{v})$ was used $(\mathrm{r}=0.42$ to 0.43$)$ compared to the porous ceramic cup $(\mathrm{r}=0.36)$. These differences were relatively lower when compared to the results from the Experiment II. The $\mathrm{K}$ contents in diagnostic leaf of melon nutritional status at 40 DAT correlated in a positive and weak way with $\mathrm{K}^{+}$ concentrations in substrate solution from both extractors, in such a way that there was no distinction in correlation degree $(\mathrm{r}=0.26)$ (Table 2$)$. The weak correlation between $\mathrm{K}$ concentrations of the substrate solution, for both extraction methods, with the $\mathrm{K}$ contents in diagnostic leaf of bell pepper (Table 3), if compared to the strong correlations obtained in the melon experiment (Table 2), can be explained by the differences in initial concentration of $\mathrm{K}$ in the substrates used in these two experiments (24.8 and $331.3 \mathrm{mg} \mathrm{L}^{-1}$ for experiments with melon and bell pepper, respectively). According to Pardossi et al. (2011), the suitable concentration of $\mathrm{K}$ in substrate solution acquired by aqueous extract $1: 1.5(\mathrm{v} / \mathrm{v})$ varies from 12 to $45 \mathrm{mg} \mathrm{L}^{-1}$. Thus the initial high concentration of $\mathrm{K}$ in substrate solution of the experiment with bell pepper did not allow the increase of $\mathrm{K}$ concentration in nutrient solution and in the substrate solution to promote variations in the $\mathrm{K}$ contents in the plant, as observed by Wamser et al. (2017) in this same experiment with bell pepper. On the other hand, Gratieri et al. (2013), in this same experiment with melon, observed increase in $\mathrm{K}$ contents in the plant with the increasing $\mathrm{K}$ in nutrient solution and, likewise, in substrate solution, justifying the strong correlation found.

The use of porous ceramic cup extractor proved to be an adequate method to acquire substrate solution with the aim to determine its chemical attributes. Supporting this statement, it is possible to highlight, initially, the strong correlation between porous ceramic cup extractor method and the aqueous extract $1: 1.5(\mathrm{v} / \mathrm{v})$ for all chemical attributes of the substrate solution, as shown in Experiment I (Table 1). Likewise, there was strong correlation between these solution analysis methods for $\mathrm{N}, \mathrm{NO}_{3}{ }^{-}$ and $\mathrm{K}$, as shown in Experiments 2 and 3 (Tables 2 and 3 ).

Another feature regarding the porous ceramic cup extractor is the proximity of linear regression coefficients to 1.0 for all attributes analyzed, except $\mathrm{N}-\mathrm{NO}_{3}$ and total $\mathrm{N}$ determined by analytical method, in Experiment I (Figures 1, 2 and 3). These regression coefficients near 1.0 imply the good accuracy of the method when compared to analytical method of aqueous extract 1:1.5 (v/v). It is highlighted, however, the need to correct the values of chemical attributes determined in the substrate solution, obtained by porous ceramic cup extractor, in order to be similar to those obtained by aqueous extract methods in the different dilutions in comparison. This correction can be done using Equation 1. The need for this adjustment was also observed by Souza et al. (2013). Based on these adjusted values it is possible to compare the results of the chemical attributes obtained with the standard values found in the literature for the most various aqueous extracts or saturation extracts. As an example, Pardossi et al. (2011) present the suitable values for cultivation in substrate of $\mathrm{EC}, \mathrm{pH}$, macronutrients, micronutrients (except $\mathrm{Mo}$ ) and $\mathrm{Na}$, considering aqueous extracts at dilutions of $1: 1.5$, $1: 2.5$ and $1: 5(\mathrm{v} / \mathrm{v})$.

Another feature that endorses the use of porous ceramic cup extractor for substrate solution extraction is the moderate correlation observed between the $\mathrm{N}$ content in diagnostic leaf of nutritional status of melon and bell pepper with $\mathrm{N}$ concentration in substrate solution acquired by this method (Tables 2 and 3). Likewise, there is a strong correlation between the $\mathrm{K}$ content in diagnostic leaf with $\mathrm{K}$ concentration in substrate solution found in Experiment II with melon (Table 2).

According to Abreu et al. (2007a), a good method to extract nutrients from the substrate solution should be related to nutritional and production aspects of a certain crop. Thus, our research brings the first inference regarding this correlation, mainly about the $\mathrm{N}$ and $\mathrm{K}$ contents in diagnostic leaf of the studied crops, since the existing studies regarding the porous ceramic cup extractor method are limited to correlating the results with those of other substrate solution extraction methods (MOTA et al., 2011; SAMBO et al., 2011; MARQUES et al., 2020).

The specific $\mathrm{NO}_{3}{ }^{-}$and $\mathrm{K}^{+}$ion meters proved to be suitable to a rapid determination of $\mathrm{N}$ and $\mathrm{K}$ concentrations of substrate solution acquired by porous ceramic cup extractors. Supporting this statement, it is possible to highlight the great accuracy of specific ion method in the analysis of $\mathrm{NO}_{3}{ }^{-}$and $\mathrm{K}^{+}$compared to the analytical method in Experiment I (Table 1). Another positive feature of the use of specific ions meters is that the analysis of $\mathrm{N}-\mathrm{NO}_{3}{ }^{-}$and $\mathrm{K}^{+}$can be done immediately after the substrate solution extraction. On the other hand, in analytical determinations, whose samples were sent to the routine lab, the time between the substrate solution extraction and the effective analysis of solution samples was 24 days, compromising the decision making for nutritional intervention of the cropping. Furthermore, the lower linear correlation regression coefficient for nitrate when substrate solution was analyzed by analytical method, when compared to specific ion meter (Figure 2), may be due to the delay in analyzing. According to Apha, Awwa and Wef (2018), nitrates must be analyzed within a maximum period of 48 hours in samples 
stored un-acidified below $6{ }^{\circ} \mathrm{C}$ without freezing, or preserved with sulfuric acid and stored from 0 to $6^{\circ}$ $\mathrm{C}$ without freezing for up to 28 days.

The association between the porous ceramic cup extractors for acquiring substrate solution with specific $\mathrm{NO}_{3}{ }^{-}$and $\mathrm{K}^{+}$ion meters constitutes a suitable method for the evaluation of the main chemical attributes of the substrate during the crop season. This statement is supported by the positive and moderate correlation between $\mathrm{NO}_{3}^{-}$and $\mathrm{K}^{+}$ concentrations, determined by this association with $\mathrm{N}$ and $\mathrm{K}$ contents in bell pepper diagnostic leaf (Experiment III) and similar to the standard method, using aqueous extracts 1:1.5 (v/v) and analytical determination of these nutrients (Table 3). Similar results were reported by Mota et al. (2014) when correlating the concentrations of $\mathrm{NO}_{3}{ }^{-}$and $\mathrm{K}^{+}$in substrate solution, determined by specific ion meters, with $\mathrm{N}$ and $\mathrm{K}$ contents respectively in the shoot of gerbera plant.

\section{CONCLUSIONS}

The results of the present research indicate that the grower can use the porous ceramic cup extractors associated with the specific ion meters as tools to acquire substrate solution and for reliable determination of its chemicals attributes, assuring agility in the decision making related to nutrition managing of melon and bell pepper grown in soilless nutrient solution.

The values of $\mathrm{EC}, \mathrm{pH}$ and macronutrients of the coconut fiber substrate solution acquired by porous ceramic cup extractor have positive correlations with the values acquired by aqueous extract 1:1.5 (v/v) method when analyzed by analytical method in routine lab.

\section{ACKNOWLEDGMENTS}

The authors acknowledge the retired Professor of Federal Institute Sul de Minas Gerais, Luiz Augusto Gratieri, for the collaboration in the experiment conduction in Muzambinho (MG, Brazil), and the São Paulo Research Support Foundation for funding the research project of the second author.

\section{REFERENCES}

ABREU, M. F. et al. Extração de substratos para obtenção da concentração de micronutrientes disponíveis para a rúcula. Horticultura brasileira, 5: 411-417, 2007a.
ABREU, M. F. et al. Extratores aquosos para a caracterização química de substratos para plantas. Horticultura Brasileira, 25: 184-187, 2007b.

APHA - American Public Health Association; AWWA - American Water Works Association; WEF - Water Environment Federation. "4500-NO3NITROGEN (NITRATE)", Standard Methods For the Examination of Water and Wastewater. 2018. Disponivel em: https:// www.standardmethods.org/doi/suppl/10.2105/ SMWW.2882.089\#. Acesso em: 10 ago. 2021.

BLANCO, F. F. Manual de construção e utilização de extratores de cápsula porosa para obtenção da solução do solo. 1. ed. Teresina, PI: Embrapa MeioNorte, 2006. 36 p. (Documentos, 142).

FERMINO, M. H. Substratos: composição, caracterização e métodos de análise. Guaíba, RS: Agrolivros, 2014. 112 p.

FURLANI, P. R. et al. Cultivo hidropônico de plantas. Campinas, SP: Instituto Agronômico, 1999. 52 p. (Boletim Técnico, 180).

GAVILÁN, M. U. et al. Effects of Fertigation Duration on the Pollution, Water Consumption, and Productivity of Soilless Vegetable Cultures. HortScience, 50: 816-825, 2015.

GRATIERI, L. A. et al. Nitrogen and potassium concentrations in the nutrients solution for melon plants growing in coconut fiber without drainage. Scientific World Journal, 2013: 1-10, 2013.

JIMÉNEZ, S.; PLAZA, B. M.; LAO, M. T. Nutrient solution and nutrient soil solution parameter evolution in tomato with dynamic fertigation under saline conditions. Communications in Soil Science and Plant Analysis, 43: 265-271, 2012.

MARQUES, G. N. et al. A solução drenada pelo substrato pode ser empregada no monitoramento da condutividade elétrica e do $\mathrm{pH}$ no cultivo do morangueiro. Pesquisa Agropecuária Gaúcha, 26: 92-100, 2020.

MOTA, P. R. D. A. et al. Avaliação do pH e da condutividade elétrica do substrato sob níveis de fertirrigação e métodos de extração da solução. Revista Brasileira de Horticultura Ornamental, 17: 121-126, 2011.

MOTA, P. R. D. A. et al. Portable meters for nutritional assessment in plants of gerbera fertigated with electrical conductivity levels. Revista Brasileira de Engenharia Agrícola e Ambiental, 18: 258-262, 2014. 
NOWAKI, R. H. D. et al. Effect of nitrogen fertilization on yield and quality of watermelon, cv. Top Gun. Revista Caatinga, 30: 164-171, 2017.

OLIVEIRA, F. A. et al. Calibração de extratores providos de cápsula porosa para monitoramento da salinidade e da concentração de íons. Engenharia Agrícola, 31: 520-528, 2011.

OLIVEIRA, F. A. et al. Manejos da fertirrigação e doses de N e K no cultivo de pimentão em ambiente protegido. Revista Brasileira de Engenharia Agrícola e Ambiental, 17: 1152-1159, 2013.

OLIVEIRA, F. A. et al. Nutrição mineral do pimentão submetido a diferentes manejos de fertirrigação. Horticultura Brasileira, 33: 216-223, 2015.

PARDOSSI, A. et al. Fertigation and Substrate Management in Closed Soilless Culture. Pisa: University of Pisa. 2011. 63 p.

SAMBO, P. et al. Comparison of Different Methods to Extract Soil-Water from Containerized Substrates. Acta Horticulturae, 922: 369-374, 2011.

SOUZA, E. R. et al. Comparação de métodos de extração da solução do solo. Revista Brasileira de Engenharia Agrícola e Ambiental, 17: 510-517, 2013.

WAMSER, A. F. et al. Influence of drainage and nutrient-solution nitrogen and potassium concentrations on the agronomic behavior of bellpepper plants cultivated in a substrate. PloS ONE, 12: e0180529, 2017.

WRIGHT, R. D. et al. Monitoring nutrients in large nursery containers. 2009. Disponível em: $<$ https://www.pubs.ext.vt.edu/430/430-070/430-

070.html >. Acesso em: 11 jun. 2019.

YONG-BEOM, L.; EUN-YOUNG, C.; KI-YOUNG, C. Scheduling Non-drainage Irrigation in Coir Substrate Hydroponics with Different Percentages of Chips and Dust for Tomato Cultivation using a Frequency Domain Reflectometry Sensor. Protected Horticulture and Plant Factory, 22: 248-255, 2013. 